
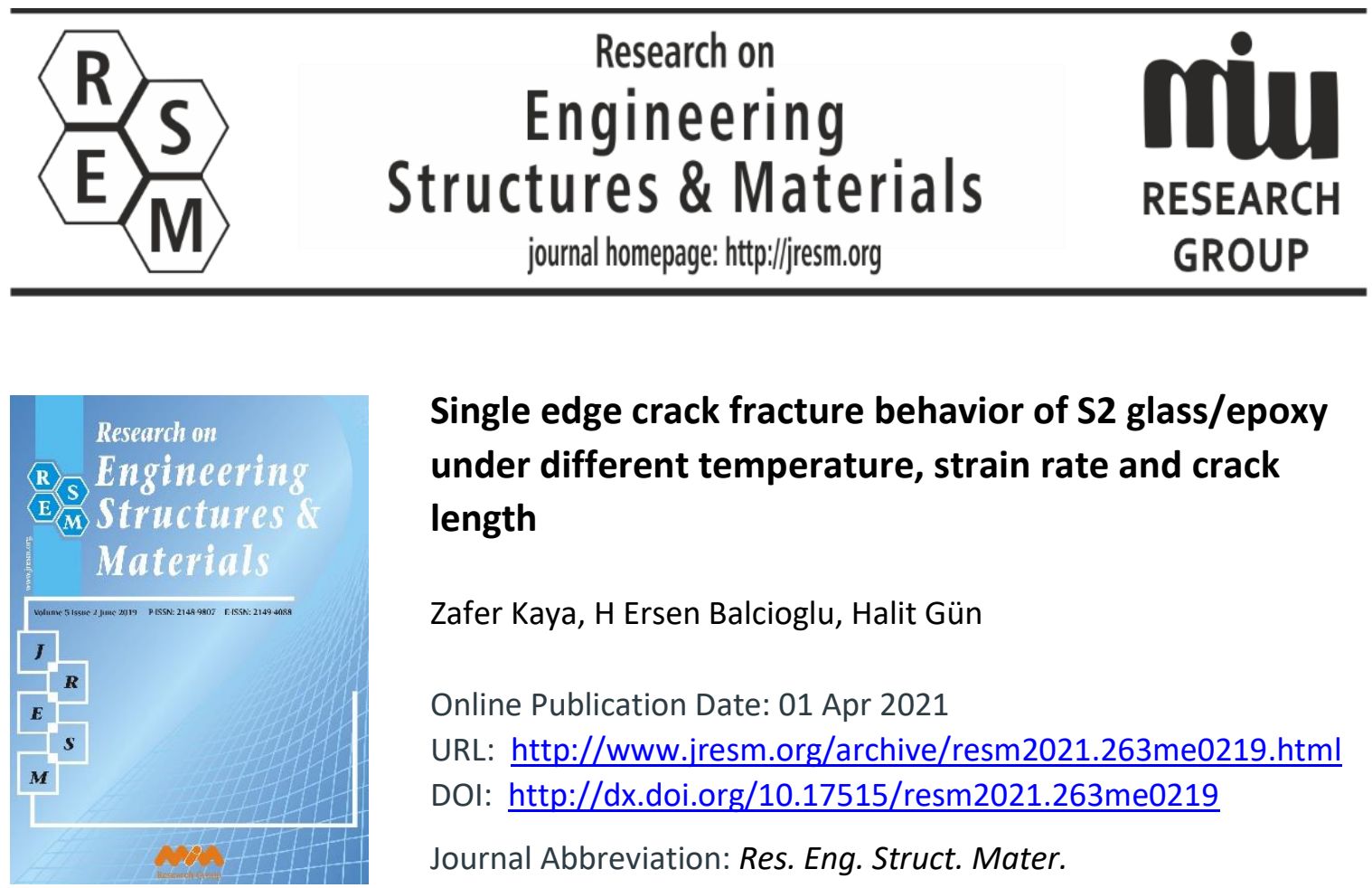

\title{
Single edge crack fracture behavior of S2 glass/epoxy under different temperature, strain rate and crack length
}

Zafer Kaya, H Ersen Balcioglu, Halit Gün

Online Publication Date: 01 Apr 2021

URL: http://www.jresm.org/archive/resm2021.263me0219.html

DOI: http://dx.doi.org/10.17515/resm2021.263me0219

Journal Abbreviation: Res. Eng. Struct. Mater.

\section{To cite this article}

Kaya Z, Balcioglu HE, Gün H. Single edge crack fracture behavior of S2 glass/epoxy under different temperature, strain rate and crack length. Res. Eng. Struct. Mater., 2021; 7(2): 297314.

\section{Disclaimer}

All the opinions and statements expressed in the papers are on the responsibility of author(s) and are not to be regarded as those of the journal of Research on Engineering Structures and Materials (RESM) organization or related parties. The publishers make no warranty, explicit or implied, or make any representation with respect to the contents of any article will be complete or accurate or up to date. The accuracy of any instructions, equations, or other information should be independently verified. The publisher and related parties shall not be liable for any loss, actions, claims, proceedings, demand or costs or damages whatsoever or howsoever caused arising directly or indirectly in connection with use of the information given in the journal or related means.

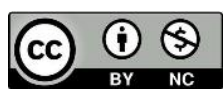

Published articles are freely available to users under the terms of Creative Commons Attribution - NonCommercial 4.0 International Public License, as currently displayed at here (the "CC BY - NC"). 


\title{
Research on Engineering Structures \& Materials
}

journal homepage: http://jresm.org

Research Article

\section{Single edge crack fracture behavior of S2 glass/epoxy under different temperature, strain rate and crack length}

\author{
Zafer Kaya ${ }^{1, a}$, H Ersen Balcioglu²,b, Halit Gün ${ }^{2, c}$ \\ ${ }^{1}$ Graduate School of Natural and Applied Sciences, Ușak University, Ușak 64100, Turkey \\ ${ }^{2}$ Department of Mechanical Engineering, Ușak University, Ușak 64100, Turkey
}

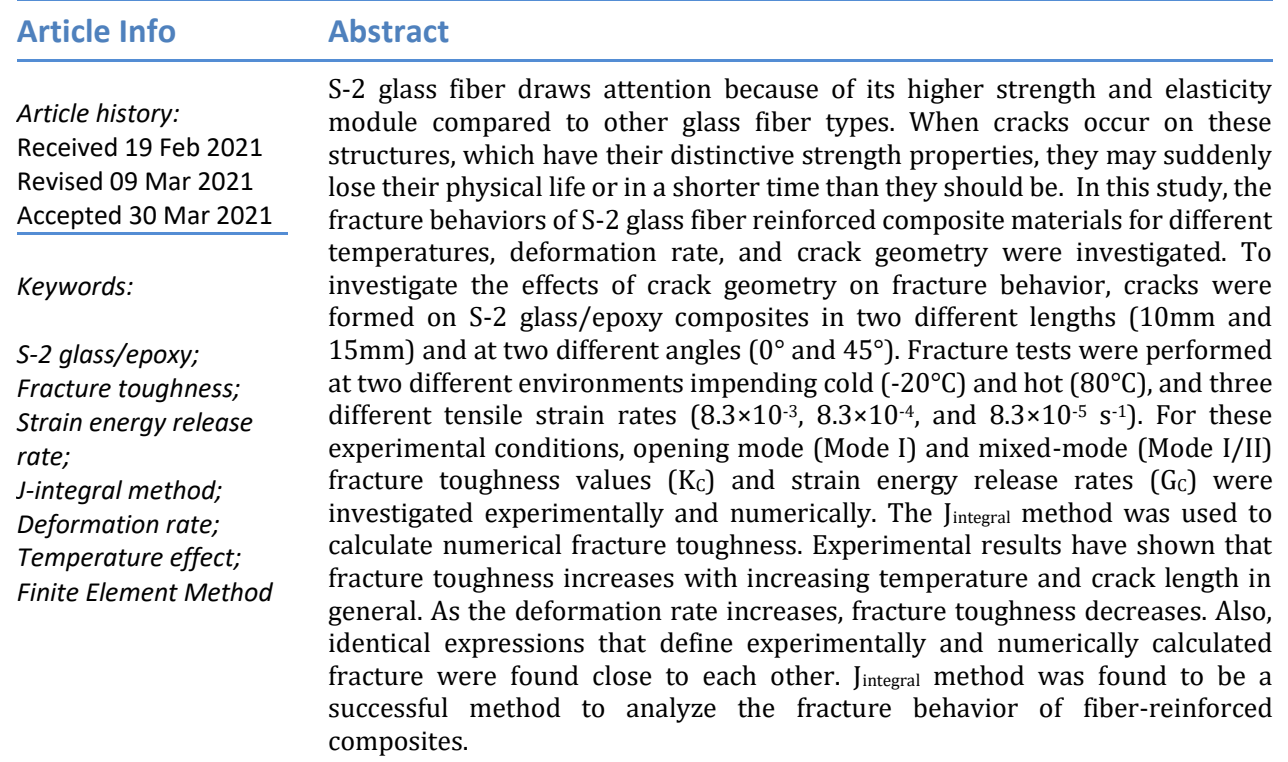

(C) 2021 MIM Research Group. All rights reserved.

\section{Introduction}

In fiber-reinforced composite materials, cracks may occur on them during their production or after external effects. Crack and following fracture damage can create situations that will result in serious losses in a structure. Crack negatively affects both the strength and physical life of the materials. The behavior of the crack should be analyzed to know the safe physical life and safe usage conditions of the composite materials that have brittle structure and crack. The geometry of the crack, environmental factors (such as temperature and humidity), and the magnitude of the load affecting the material are the main factors affecting the crack behavior. In a composite structure having cracks, the length of the crack directly affects the fracture toughness of the material and the crack propagation rate. Therefore, it is important to know the effects of crack length on the fracture behavior of the composite material.

In their study on the crack location and crack length, Yin et al.[1] have examined the opening distance at the crack bottom as a toughness assessment criterion for the model they created in their experimental and numerical studies. Healey et al.[2] have studied the fracture behavior between layers on carbon fiber prepreg composite structure test

${ }^{*}$ Corresponding author: ersenbalcioglu06@gmail.com

a orcid.org/0000-0002-5489-3997; b orcid.org/0000-0002-8579-5142; c orcid.org/0000-0001-8107-5036

DOI: http://dx.doi.org/10.17515/resm2021.263me0219

Res. Eng. Struct. Mat. Vol. 7 Iss. 2 (2021) 297-314 
specimens with crack lengths between $20-40 \mathrm{~mm}$. Loutas et al. [3] studied Mod I fracture behavior in metal composites. They used $28 \mathrm{~mm}, 34.5 \mathrm{~mm}, 54.5 \mathrm{~mm}$, and $67.6 \mathrm{~mm}$ anterior crack lengths in their studies. Andric and Curtin [4] modeled fractured specimens with a central crack ranging from $2 \mathrm{~mm}$ to $15 \mathrm{~mm}$ in their fracture studies. Bosbach et al. [5] measured the strain energy release rate between fiber and matrix at opening distances between $53 \mathrm{~mm}$ and $78 \mathrm{~mm}$ of the crack. Kaushik and Ghosh [6] evaluated the crack in terms of strain energy release rate and fracture toughness in crack expansions between $60 \mathrm{~mm}$ and $110 \mathrm{~mm}$ in polytetrafluoroethylene (PTFE) prepreg composite plates. Insausti et al.[7] have performed a numerical analysis for double cantilever beam test specimens to determine the crack length, the compliance, and the energy release rate.

The position of the crack or the angle of load that forces the crack to progress causes the development of different fracture damage modes such as opening mode (Mode I), in-plane shearing mode (Mode II), out-of-plane shearing mode (Mode III) or mixed mode. Mousavi et al.[8] Mode I, Mode II and Mod I/II; Aliha and Mousavi [9] Mod I and Mod I/II; Kaynan et al.[10] Mod I/II for carbon fiber prepregs; Li et al.[11] Mod I/II; Ravindran et al.[12] Mode II studied experimental specimens with different crack lengths in fracture modes. Shahani et al. [13] experimentally investigated the inter-laminar fracture behavior under Mode I loading in a glass/epoxy composite structure. Torabi et al. [14] studied Mod I/II fracture toughness in nanocomposites. They worked on experiment specimens with $1 \mathrm{~mm}$, $2 \mathrm{~mm}$, and $4 \mathrm{~mm}$ length central cracks.

One of the factors affecting fracture damage is environmental factors such as temperature and humidity [15]. Although the effects of these factors have been an issue studied since the 1980s, there is still no standard test method. In the literature, the results of some studies on this subject showed that the fracture toughness increased with increasing temperature. Such that, fracture toughness investigation in a carbon epoxy laminated structure, the inter-laminar fracture toughness generally increases with the increase in temperature for Mode I crack tip opening status [16,17]. Foyouzat et al. [18] investigated the Mode I fracture toughness of shape memory polymers (SMP) between $20^{\circ} \mathrm{C}$ and $100^{\circ} \mathrm{C}$ temperatures. Arash Farshidi et al. [19] in their experiments in foam core sandwich composites $-20^{\circ} \mathrm{C}$ and room temperature $\left(23^{\circ} \mathrm{C}\right)$, they found a decrease in Mod I and Mod I/II fracture toughness as the temperature dropped. M. Fakhri et al. [20] performed crack analysis of hot mix asphalt at $5^{\circ} \mathrm{C}, 15^{\circ} \mathrm{C}$, and $25^{\circ} \mathrm{C}$ temperatures under Mod I, Mod II, and Mod I/II loading conditions. Khashaba et al.[21] performed some experiments to investigate the mechanical properties of Epocast 50-A1/epoxy at room temperature and $50^{\circ} \mathrm{C}$. Pan et al.[22] have investigated thermo-mechanical response and morphology of three-dimensional knitting carbon/epoxy composites under different environment temperatures such as $25^{\circ} \mathrm{C}, 60^{\circ} \mathrm{C}, 90^{\circ} \mathrm{C}$, and $120^{\circ} \mathrm{C}$. Pini et al. [23] examined the strain energy release rate at $0^{\circ} \mathrm{C}$ and $60^{\circ} \mathrm{C}$ temperature ranges for cracked test specimens of laminated carbon fiber composite. In another study, Rahmani et al. [24] determined in their experimental study, which performed at the temperature range of $-80^{\circ} \mathrm{C}$ to $+22^{\circ} \mathrm{C}$, that a reduction in the fracture energy absorption capacity of the composite structure at very low temperature occurred.

Another factor affecting the fracture behavior of the composite structure is the strain rate effect. Aktaş et al. [25] investigated the mechanical behavior properties of glass/epoxy laminated composite plates at different deformation rates of $0.005 \mathrm{~s}^{-1}, 0.0005 \mathrm{~s}^{-1}$, and $0.00005 \mathrm{~s}^{-1}$. Also, Jia et al. [26] investigated Mode I fracture toughness of polyurethane adhesive at $0.5 \mathrm{~mm} / \mathrm{min}, 50 \mathrm{~mm} / \mathrm{min}, 500 \mathrm{~mm} / \mathrm{min}$ loading speeds.

S-2 glass/epoxy laminated composite structures are frequently used as reinforcement materials in composite applications that require high strength. Sometimes these composite structures can be used in a body material of cold storage tank. Also, due to its lightness, it 
is used as a building material in wind turbines working in a hot environment. Therefore, it is important to know the fracture behavior of S-2 glass fiber reinforced composite having different crack geometry under cold and hot environments and at different deformation rates. In this context, $\mathrm{S}-2$ glass/epoxy laminated composites having single edge crack length $(10 \mathrm{~mm}$ and $15 \mathrm{~mm})$ were tested in two different temperatures $\left(-20^{\circ} \mathrm{C}\right.$ and $\left.80^{\circ} \mathrm{C}\right)$ and three different deformation rates $\left(8.3 \times 10^{-3}, 8.3 \times 10^{-4}\right.$, and $\left.8.3 \times 10^{-5} \mathrm{~s}^{-1}\right)$ for Mode I and Mode I/II crack tip opening status. Also, the fracture behavior of S-2 glass/epoxy laminated composites was modeled using the ANSYS finite element program and fracture toughness and J integral values were calculated for each experimental parameter. When the accessible literature was examined, it was seen that the fracture behavior of S-2 glass reinforced composite structures was not investigated depending on the temperature and deformation rate changes. The response of different crack lengths to these variables has been the main research subject of the study. The combination of experimental and finite element studies will contribute to the literature.

\section{Material and Methods}

\subsection{Production of Composite Materials}

Vacuum resin transfer molding method (VARTM) was used to the manufacturing of composite plates having 8 laminas. The reinforcement material is woven S-2 glass fabric has $190 \mathrm{~g} / \mathrm{m}^{2}$ weight, and $130 \mu \mathrm{m}$ thickness. Two-component resin consisting of epoxy (Hexion MGS L285) and hardener (Hexion H287) was used as the matrix material. Technical specifications of reinforcement material and the matrix material are shown in Table 1.

Table 1. The material properties of fiber material and epoxy resin

\begin{tabular}{ccc}
\hline Material Properties & $\begin{array}{c}\text { Fibre Material } \\
\text { (S-2 Glass) [27] }\end{array}$ & $\begin{array}{c}\text { Matrix Material } \\
\text { (Hexion Epoxy Resin) [28] }\end{array}$ \\
\hline Young's modulus (E) in GPa & $86-93$ & 3.2 \\
Shear Modulus (G) in GPa & $35-39$ & 1.18 \\
Poisson's ratio (U) & 0.21 & 0.36 \\
Tensile Strength in MPa & $4700-4800$ & $70-80$ \\
Compressive Strength in MPa & $4000-5000$ & $120-140$ \\
\hline
\end{tabular}

During the tests, load-displacement curves were saved for each specimen utilizing the computer-controlled tensile test machine. The displacement values for specimens under load were observed using a video extensometer capable of recording bidirectional deformation. Before the fracture tests, the test specimens were kept at the relevant test temperature and ensured to reach an equal temperature with the environment. Each experiment was repeated three times and the averages of these three experiments were used in the study.

Linear Elastic Fracture Mechanics (LEFM) is the whole of analytical expressions used in the study of fracture mechanics and developed based on the principle that all behaviors in the material remain within elastic limits. The basic principle of this method is to express the stresses formed at the crack tip depending on the stress applied to the part, the length and direction of the crack. The principles of LEFM was used to examine the fracture behavior of fiber-reinforced composite material $[4,13,32]$. 


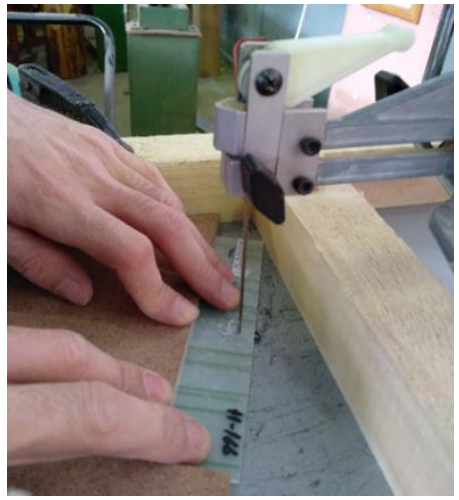

(a)

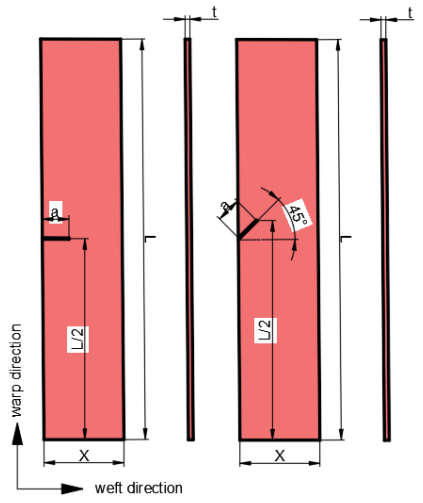

(b)

Fig. 1 Single edge crack test specimen (a) crack creation (b) test sample sizes

The produced S-2 glass/epoxy composite plates were cut in the warp direction with the dimensions $\mathrm{L}=150 \mathrm{~mm}$ and $\mathrm{X}=30 \mathrm{~mm}$. Then cracks of $\mathrm{a}=10 \mathrm{~mm}$ and $\mathrm{a}=15 \mathrm{~mm}$ length on the fracture test specimens were created from the single edge of the specimen with a jigsaw at $0^{\circ}$ and $45^{\circ}$ angles according to the weft axis as shown in Figure 1. The thickness of each crack is $0.5 \mathrm{~mm}[8,29-31]$.

\subsection{Fracture Tests}

The fracture tests were carried out in the Shimadzu AG-X model tensile testing device having the thermostatic chamber. The loading capacity of the test machine is $100 \mathrm{kN}$. The hot and cold environments required for fracture tests were created inside the thermostatic chamber of the test device. Fracture tests performed in cold and hot environments in 5 repetitions have enabled the polymer-built composite material to determine ductile and brittle deformation behavior. Thanks to the electrical heater of the thermostatic chamber the environment was heated to $80^{\circ} \mathrm{C}$, and to obtain a cold environment $\left(-20^{\circ} \mathrm{C}\right)$ Nitrogen gas was used (Figure 2). Fracture tests were performed three different strain rates of $8.3 \times 10^{-3} \mathrm{~s}^{-1}, 8.3 \times 10^{-4} \mathrm{~s}^{-1}$, and $8.3 \times 10^{-5} \mathrm{~s}^{-1}$. To obtain strain rates of $8.3 \times 10^{-3} \mathrm{~s}^{-1}, 8.3 \times 10^{-4} \mathrm{~s}^{-1}$, and $8.3 \times 10^{-5} \mathrm{~s}^{-1}$, test specimens were subjected to tensile testing at jaw feed rates of 50 $\mathrm{mm} / \mathrm{min}, 5 \mathrm{~mm} / \mathrm{min}$ and $0.5 \mathrm{~mm} / \mathrm{min}$, respectively.

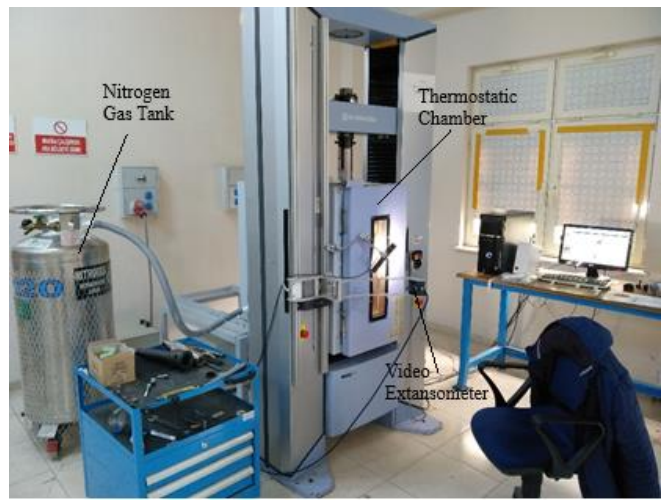

Fig. 2 Shimadzu AG-X $100 \mathrm{kN}$ universal test device 
The critical stress intensity factor is determined by the fracture test. This factor is calculated according to the damage condition of the crack opening (Mode I), sliding (Mode II), opening sliding (Mode I/II). The critical stress intensity factor $\left(\mathrm{K}_{\mathrm{c}}\right)$ for the test specimen with a single edge crack is calculated according to the following Eq.1.

$$
K_{c}=\frac{P_{a p p} \sqrt{\pi a}}{X t} y\left(\frac{a}{X}\right)
$$

In this formula, $P_{a p p}$, represents the applied load, $a$ crack length, $X$ specimen width, $t$ specimen thickness, $y\left(\frac{a}{X}\right)$ geometric factor [33-35].

\subsection{Mod I Fracture Toughness}

In the Mode I crack tip opening status, the normal component of the stress influence vertical to the crack surface. This stress forces to damage by only the opening of the crack tip. Since the Mode I damage type is the most critical damage type among brittle composite materials, it is the most widely studied case in fracture mechanics studies. In Mode I, where the crack tip is forced to open (crack angle $\alpha=0^{\circ}$ ), it is called Fracture Toughness (KIC) when the stress intensity factor reaches the critical value. Expressed in $\mathrm{K}_{\mathrm{IC}}$ (Eq. 2).

$$
K_{l c}=\frac{P_{c r} \sqrt{\pi a}}{X t} y_{l}\left(\frac{a}{X}\right)
$$

Unlike from Eq. 1, in the formula; $P_{c r}$ represents the damage load and $y_{l}\left(\frac{a}{x}\right)$ represents the geometric factor for the opening mode. $y_{l}\left(\frac{a}{x}\right)$ geometric factor values depend on crack length, temperature, and deformation rate. These values were calculated by using the finite element method. For this aim, single edge cracked test models were created in the finite element program ANSYS according to the experimental fracture test dimensions of specimens. The following steps have been applied to calculate the $y_{I}\left(\frac{a}{x}\right)$ geometric factor value.

- A randomly selected load of $\mathrm{P}=1000 \mathrm{~N}$ was applied to these models created for each test condition.

- The value of $\left(K_{I C}\right)_{N u m}$ for Mode I obtained by using the "Fracture Tool" of the program.

- Then, the geometric factor value $y_{I}\left(\frac{a}{x}\right)$ was calculated by substituting the obtained fracture toughness value in Eq. $3[35,36]$.

$$
y_{I}\left(\frac{a}{X}\right)=\frac{\left(K_{I C}\right)_{N u m} \cdot w t}{P \cdot \cos \alpha \sqrt{\pi a}}
$$

In the case of Mode I for each experiment parameters, $y_{l}\left(\frac{a}{X}\right)$ values are obtained as in Table 2. 
Table 2. Geometric dimension factor values obtained from ANSYS finite element program for Mode I (opening mode).

\begin{tabular}{ccccc}
\hline \multirow{2}{*}{$\begin{array}{c}\text { Deformation } \\
\text { Rate }\left(\mathrm{s}^{-1}\right)\end{array}$} & $-20^{\circ} \mathrm{C}$ & $80^{\circ} \mathrm{C}$ & $-20^{\circ} \mathrm{C}$ & $80^{\circ} \mathrm{C}$ \\
\hline $8.3 \times 10^{-3}$ & 1.9821 & 2.1788 & 3.1289 & 3.4570 \\
$8.3 \times 10^{-4}$ & 1.8628 & 2.3603 & 3.3696 & 3.7612 \\
$8.3 \times 10^{-5}$ & 2.2449 & 2.5211 & 3.5655 & 4.0238 \\
\hline
\end{tabular}

\subsection{Mod I/II Fracture Toughness}

If the direction of the applied load is parallel to the crack, occurred stress at crack tip force the crack by shearing and this condition is called pure shearing mode (Mode II). In some cases, the crack tip is forced to both open and shear. The state where the effects of Mode I and Mode II are seen together is called mixed mode, namely Mode I/II. In this case, two stress intensity factor components are formed at the crack tip. The stress intensity factor value reaches the critical value as soon as the specimen breaks and the fracture toughness value is expressed in $K_{\text {mix }}$ [37-39]. $K_{1}$ and $K_{11}$ toughness values given in Eq. 4 and 5 are the opening and shearing components of $K_{\text {mix }}$ toughness value given in Eq. 6 [34]. Mod Mode I/II fracture behavior of S-2 glass/epoxy composites was investigated for the crack angle of $\alpha=45^{\circ}$.

$$
\begin{aligned}
& K_{l}=\frac{P_{c r} \cos 45^{\circ} \sqrt{\pi a}}{X t} y_{m \imath}\left(\frac{a}{X}\right) \\
& K_{l l}=\frac{P_{c r} \sin 45^{\circ} \sqrt{\pi a}}{X t} y_{m \iota l}\left(\frac{a}{X}\right) \\
& K_{m i x}=\sqrt{K_{l}^{2}+K_{l l}^{2}}
\end{aligned}
$$

For Mode I/II, $y_{m \iota}\left(\frac{a}{x}\right)$ and $y_{m \iota l}\left(\frac{a}{x}\right)$ are a function of geometric dimension factor values, crack length, crack angle $(\alpha)$, temperature, and deformation rate. The $y_{m l}\left(\frac{a}{x}\right)$ and $y_{m u l}\left(\frac{a}{x}\right)$ geometrical factor value required to calculate the Mode I/II fracture toughness value was calculated by following the same procedure. The geometric factor values for the opening $\left(f_{m l}\left(\frac{a}{w}\right)\right)$ and shearing $\left(f_{m u l}\left(\frac{a}{w}\right)\right)$ directions were calculated by substituting the obtained fracture toughness values in places of Eqs. 7-8, respectively [35,36].

$$
\begin{aligned}
& f_{m \iota}\left(\frac{a}{w}\right)=\frac{\left(K_{\imath}\right)_{N u m} \cdot w t}{P \cdot \cos \alpha \sqrt{\pi a}} \\
& f_{m \iota l}\left(\frac{a}{w}\right)=\frac{\left(K_{\iota l}\right)_{N u m} \cdot w t}{P \cdot \sin \alpha \sqrt{\pi a}}
\end{aligned}
$$

The geometric factors $\left(y_{m \imath}\left(\frac{a}{x}\right)\right.$ and $\left.y_{m u}\left(\frac{a}{x}\right)\right)$ for the Mod I/II crack tip opening status were given in Table 3. 
Table 3. Geometric factor values obtained from ANSYS finite element program for Mode I/II

\begin{tabular}{cccccccccc}
\hline & \multicolumn{4}{c}{$y_{m \imath}\left(\frac{a}{X}\right)$} & \multicolumn{4}{c}{$y_{\text {mи }}\left(\frac{a}{X}\right)$} \\
\cline { 2 - 9 } $\begin{array}{c}\text { Deformation } \\
\text { Rate }\left(\mathrm{s}^{-1}\right)\end{array}$ & \multicolumn{2}{c}{$\mathrm{a}=10 \mathrm{~mm}$} & \multicolumn{2}{c}{$\mathrm{a}=15 \mathrm{~mm}$} & $\mathrm{a}=10 \mathrm{~mm}$ & $\mathrm{a}=15 \mathrm{~mm}$ \\
\cline { 2 - 9 } & $-20^{\circ} \mathrm{C}$ & $80^{\circ} \mathrm{C}$ & $-20^{\circ} \mathrm{C}$ & $80^{\circ} \mathrm{C}$ & $-20^{\circ} \mathrm{C}$ & $80^{\circ} \mathrm{C}$ & $-20^{\circ} \mathrm{C}$ & $80^{\circ} \mathrm{C}$ \\
\hline $8.3 \times 10^{-3}$ & 1.4063 & 1.5344 & 1.8463 & 2.0208 & 0.7970 & 0.8949 & 1.0142 & 1.1512 \\
$8.3 \times 10^{-4}$ & 1.5020 & 1.6553 & 1.9847 & 2.2078 & 0.8653 & 0.9808 & 1.1152 & 1.2851 \\
$8.3 \times 10^{-5}$ & 1.5747 & 1.7523 & 2.0912 & 2.3509 & 0.9319 & 1.0708 & 1.2109 & 1.4145 \\
\hline
\end{tabular}

As seen in Tables 2 and 3, the geometric factor value is affected by the mechanical properties of the material, ambient temperature, crack position and length, and deformation rate values. Geometric factor values are a concept that directly changes the fracture toughness and strain energy release rate studied experimentally. Therefore, when examining the fracture behavior of laminated composites, geometric dimension factor value should be calculated for each test parameter.

\subsection{Determination of Strain Energy Release Rate}

Another parameter used to express the elastic behavior of the crack tip is the strain energy release rate $\left(\mathrm{G}_{\mathrm{c}}\right)$. The $\mathrm{G}_{\mathrm{c}}$ value can also be expressed as the energy used up as the crack proceeds as much as a unit area. For the orthotropic material, in the plane stress state, in the warp direction and the weft direction, the value of strain energy release rate is calculated by Equation 9-10 [9,40,41].

$$
\begin{gathered}
G_{I C}=\frac{K_{I C}^{2}}{E_{I}} \\
G_{I I C}=\frac{K_{I I C}^{2}}{E_{I I}}
\end{gathered}
$$

The mixed-mode (Mode I/II) strain energy release rate $\left(\mathrm{G}_{\text {mix }}\right)$ is calculated using Equation 11. $K_{\mathrm{lc}}$ and $\mathrm{K}_{\mathrm{uc}}$ toughness values are opening and sliding components of fracture toughness in the case of Mod I/II. For the S-2 glass/epoxy composite, $E_{I}$ warp direction and $E_{I I}$ weft direction are the modulus of elasticity.

$$
G_{\text {mix }}=G_{l c}+G_{l l c}
$$

Similar to the mixed fracture toughness formula, here $G_{l c}$ and $G_{u c}$ are components of the mixed-mode strain energy release rate value in the opening and shearing direction [42].

\subsection{Finite Element Analyses}

Using Ansys Workbench V19, different models were created for each experiment condition and finite element analysis was made, fracture toughness and J Integral data were calculated. In the finite element model, the same as in experimental studies, the geometric model fixed from the bottom side, and the tensile load was applied from the upper side. The models (Mod I and Mod I/II) were created using 6981 nodes and 3346 triangular elements. The mesh structure around the crack tip was rearranged so that the smallest element size was about $0.05 \mathrm{~mm}$. The singularity of the stress/strain area was analyzed using single type elements around the first ring of the crack tip elements (Figure 3). 


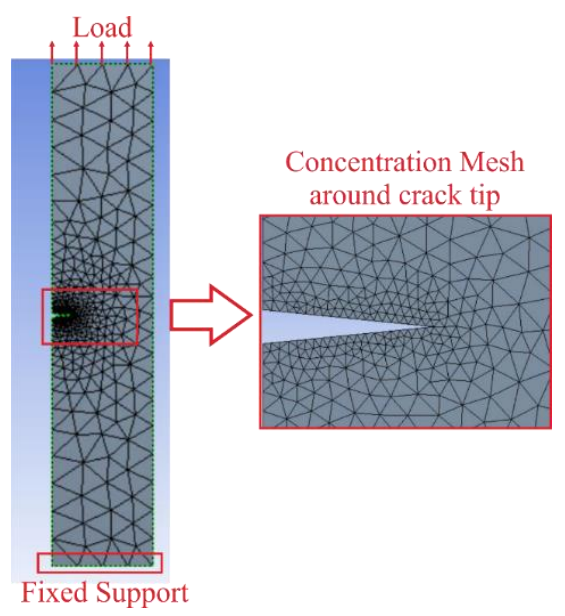

Fig. 3 Geometric model of single edge cracked specimens

Table 4. Mechanical properties of S-2 glass/epoxy laminated composite material in two temperature conditions

\begin{tabular}{|c|c|c|c|c|c|c|c|}
\hline \multicolumn{2}{|c|}{ Temperature $\left({ }^{\circ} \mathrm{C}\right)$} & \multicolumn{3}{|c|}{$-20^{\circ} \mathrm{C}$} & \multicolumn{3}{|c|}{$80^{\circ} \mathrm{C}$} \\
\hline \multicolumn{2}{|c|}{$\begin{array}{l}\text { Deformation rate } \\
\qquad\left(\mathrm{s}^{-1}\right)\end{array}$} & $\begin{array}{l}m \\
\dot{b} \\
\vec{x} \\
m \\
\infty\end{array}$ & $\begin{array}{l}\stackrel{+}{0} \\
\stackrel{\vec{x}}{\vec{x}} \\
m \\
\infty \\
\infty\end{array}$ & $\begin{array}{l}\qquad \\
\dot{0} \\
\vec{x} \\
m \\
\infty \\
\infty\end{array}$ & $\begin{array}{l}m \\
\dot{m} \\
\vec{x} \\
m \\
\infty \\
\infty\end{array}$ & $\begin{array}{l}\dot{y} \\
\dot{0} \\
\vec{x} \\
m \\
\infty \\
\infty\end{array}$ & $\begin{array}{l}\stackrel{\varphi}{0} \\
\stackrel{1}{\vec{x}} \\
\text { m } \\
\infty \\
\infty\end{array}$ \\
\hline \multirow{7}{*}{ 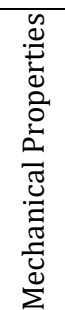 } & $\mathrm{E}_{\mathrm{I}}(\mathrm{GPa})$ & 18.59 & 18.58 & 18.62 & 16.18 & 16.29 & 16.34 \\
\hline & $\mathrm{E}_{\text {II }}(\mathrm{GPa})$ & 19.53 & 19.68 & 21.19 & 15.41 & 15.66 & 17.24 \\
\hline & $\mathrm{G}(\mathrm{GPa})$ & 2.08 & 2.57 & 3.20 & 1.32 & 1.67 & 2.05 \\
\hline & $\mathrm{Y}_{\mathrm{T}}(\mathrm{MPa})$ & 382.92 & 386.89 & 392.49 & 277.24 & 310.47 & 341.81 \\
\hline & $\mathrm{X}_{\mathrm{T}}(\mathrm{MPa})$ & 341.71 & 354.36 & 355.71 & 256.69 & 287.07 & 291.36 \\
\hline & $\mathrm{Y}_{\mathrm{C}}(\mathrm{MPa})$ & 299.69 & 305.14 & 311.56 & 192.90 & 219.16 & 244.64 \\
\hline & $\mathrm{X}_{\mathrm{C}}(\mathrm{MPa})$ & 287.67 & 301.65 & 316.69 & 185.27 & 216.71 & 264.91 \\
\hline
\end{tabular}

Mechanical experiments were conducted according to ASTM D3039, ASTM D3410, and ASTM D3518M test standards to determine the mechanical behavior of S-2 glass/epoxy laminated composites under tensile, compression and shear loads, respectively. Weft direction elasticity module $\left(E_{1}\right)$, warp direction elasticity module $\left(E_{11}\right)$, shear modulus $(G)$, warp direction tensile strength $\left(\mathrm{Y}_{\mathrm{t}}\right)$, weft direction tensile strength $\left(\mathrm{X}_{\mathrm{t}}\right)$, warp direction compressive strength $\left(\mathrm{Y}_{\mathrm{c}}\right)$ and weft direction compressive strength $\left(\mathrm{X}_{\mathrm{c}}\right)$ was found. The determined mechanical properties were given in Table 4. In addition, Poisson ratios were assumed as $\mathrm{v}_{\mathrm{xy}}=0.11, \mathrm{v}_{\mathrm{yx}}=0.18$ and $\mathrm{v}_{\mathrm{yz}}=0.18[43,44]$.

In the finite element analysis, the numerical fracture toughness and J integral value at different temperatures and strain rates were calculated. J integral represents the amount of energy per unit opening at the crack tip of the composite material $[40,45]$. 

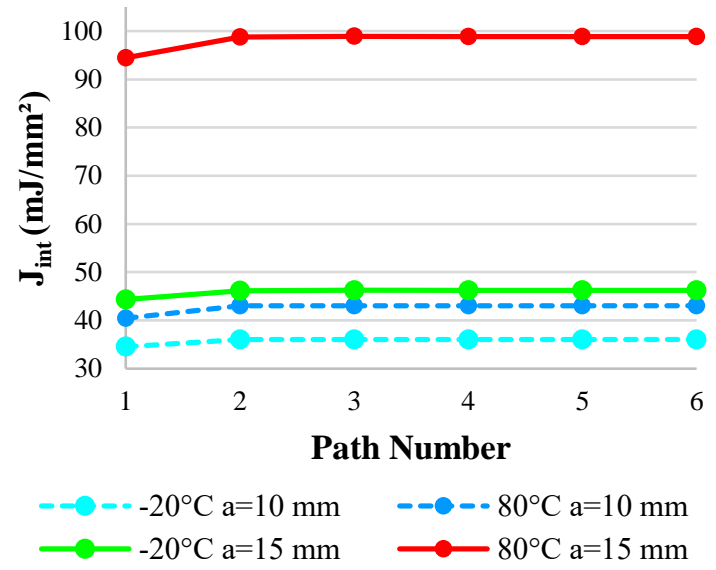

(a)

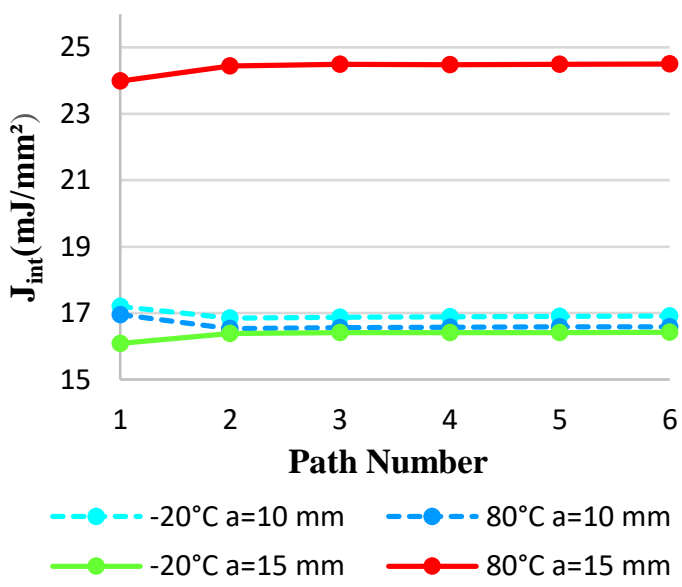

(b)

Fig. 4 J integral change from the crack tip (a) Mode I status and (b) Mode I/II status

During modeling, six paths were created in line with the crack tip onset direction starting from the crack tip. In Figure 4, J integral value changes of the samples, which were tested at different temperatures and $5 \mathrm{~mm} / \mathrm{min}$ deformation speed $\left(8.3 \times 10^{-4} \mathrm{~s}^{-1}\right)$, were given starting from the crack tip. Since a similar curve behavior occurs in other deformation rates, a single deformation rate is given. When the J integral change curves are given for the opening mode (Mode I) in Figure 4(a) are examined, it is seen that the J integral value of $15 \mathrm{~mm}$ crack length is higher. This is believed to be due to the increased energy absorption capacity of the polymer matrix, which becomes ductile with high temperatures.

In the case of mixed mode (Mode I/II) in Figure 4(b), the highest value of the J integral value is observed in the crack length of $15 \mathrm{~mm}$ and in the hottest experimental conditions. In other experimental conditions, J integral values very close to each other are seen. In the case of Mode I/II, S-2 glass/epoxy shows a more complex behavior. The reason for this situation is the effect of the energy released from the fibers in the direction of sliding while opening the crack mouth. For both crack tip opening mode conditions, when the J integral 
value in each path is examined, as they move in the direction of the displacement vector increases a little and then follow a course close to the horizontal [46-48]

\section{Results and Discussion}

\subsection{Fracture Toughness Results}

In Figure 5, the load-displacement curves obtained from the fracture tests for Mod I and Mode I/II crack tip opening status were given. Test results have shown that the S-2 glass/epoxy laminated composite has a brittle fracture behavior in a cold environment. For two different crack opening status and $10 \mathrm{~mm}$ crack length, at $-20^{\circ} \mathrm{C}$ high tensile strength was obtained. When the crack length was $15 \mathrm{~mm}$, it was more effective to brittleness at $20^{\circ} \mathrm{C}$. And according to the $80^{\circ} \mathrm{C}$ temperature, the fracture occurred at much lower forces. The deformation ability of this material is higher at low temperatures in all deformation rates, crack length, and loading modes. Generally, under the same conditions, the fracture load $\left(\mathrm{P}_{\mathrm{cr}}\right)$ in the Mode I/II crack tip opening status is higher than in the Mode I status. This is because, in the case of Mod I/II, the shearing effects force the crack mouth to open in different directions. A similar situation is seen in other studies $[49,50]$.

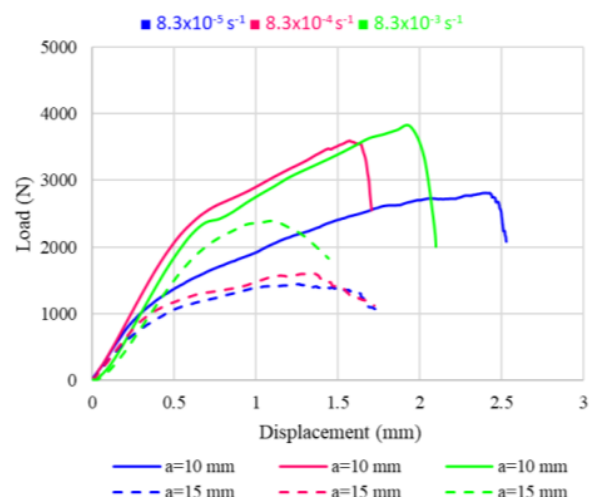

(a)

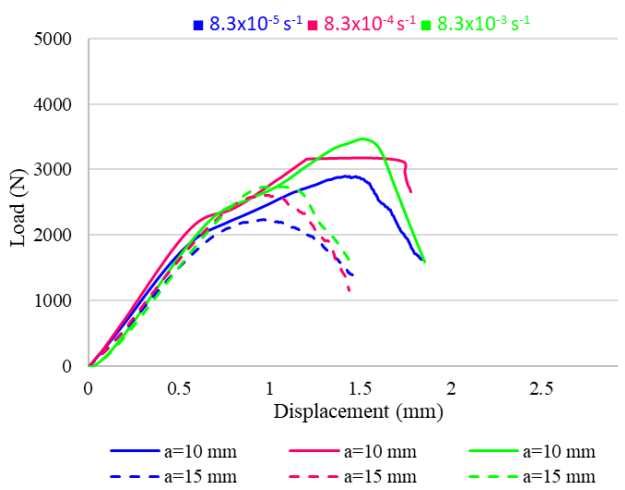

(c)

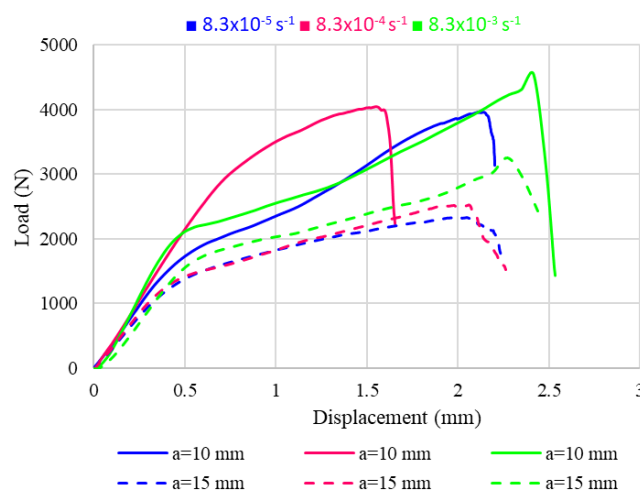

b)

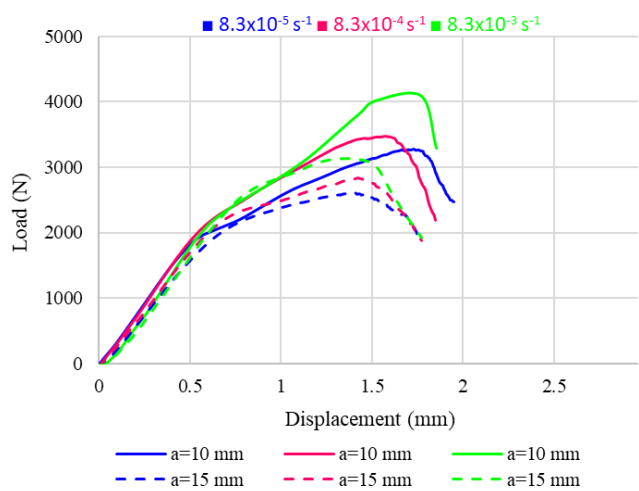

(d)

Fig. 5 Load-displacement curves, (a) Mode I at $-20^{\circ} \mathrm{C}$, (b) Mode I/II at $-20^{\circ} \mathrm{C}$, (c) Mode I at $80^{\circ} \mathrm{C}$ and (d) Mode I/II at $80^{\circ} \mathrm{C}$ 
The fracture damage load, obtained from the load-displacement curve was used to calculate the toughness values obtained from the experimental and FEM analysis. Experimental and FEM fracture toughness values were compared for Mod I and Mod I/II crack tip opening in Table 5 and Table 6, respectively.

Table 5. Experimental and FEM fracture toughness values in Mode I opening case

\begin{tabular}{|c|c|c|c|c|c|c|c|c|}
\hline \multirow{3}{*}{$\begin{array}{c}\text { Deformation } \\
\text { Rate }\left(\mathrm{s}^{-1}\right)\end{array}$} & \multicolumn{8}{|c|}{$\mathrm{a}=10 \mathrm{~mm}$} \\
\hline & \multirow{2}{*}{ 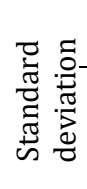 } & \multicolumn{3}{|c|}{$-20^{\circ} \mathrm{C}$} & \multirow{2}{*}{ 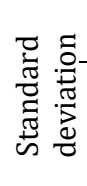 } & \multicolumn{3}{|c|}{$80^{\circ} \mathrm{C}$} \\
\hline & & $\begin{array}{c}\text { KIC(exp) } \\
\left.\text { (MPam }^{1 / 2}\right)\end{array}$ & $\begin{array}{c}\text { KIC(num) } \\
\left(\text { MPam }^{1 / 2}\right)\end{array}$ & $\begin{array}{l}\% \\
\text { Error }\end{array}$ & & $\begin{array}{c}\text { KIC(exp) } \\
\left(\mathrm{MPam}^{1 / 2}\right)\end{array}$ & $\begin{array}{c}\text { KIC(num) } \\
\left(\text { MPam }^{1 / 2}\right)\end{array}$ & $\begin{array}{c}\% \\
\text { Error }\end{array}$ \\
\hline $8.3 \times 10^{-3}$ & 27,6 & 851,77 & 858,53 & 0,8 & 25,7 & 879,54 & 884,31 & 0,5 \\
\hline $8.3 \times 10^{-4}$ & 36,4 & 847,37 & 848,98 & 0,2 & 11,9 & 870,16 & 872,26 & 0,2 \\
\hline $8.3 \times 10^{-5}$ & 25,9 & 825,54 & 828,77 & 0,4 & 40,9 & 859,85 & 866,45 & 0,8 \\
\hline \multirow{3}{*}{$\begin{array}{l}\text { Deformation } \\
\text { Rate }\left(\mathrm{s}^{-1}\right)\end{array}$} & \multicolumn{8}{|c|}{$\mathrm{a}=15 \mathrm{~mm}$} \\
\hline & \multirow{2}{*}{ 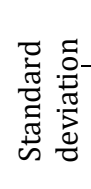 } & & $-20^{\circ} \mathrm{C}$ & & \multirow{2}{*}{ 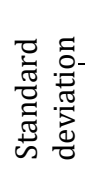 } & \multicolumn{3}{|c|}{$80^{\circ} \mathrm{C}$} \\
\hline & & $\begin{array}{c}\text { KIC(exp) } \\
\left(\text { MPam }^{1 / 2}\right)\end{array}$ & $\begin{array}{c}\text { KIC(num) } \\
\text { (MPam }^{1 / 2} \text { ) }\end{array}$ & $\begin{array}{l}\% \\
\text { Error }\end{array}$ & & $\begin{array}{c}\mathrm{K}_{\mathrm{IC}(\exp )} \\
\left(\mathrm{MPam}^{1 / 2}\right)\end{array}$ & $\begin{array}{c}\text { KIC(num) } \\
\text { (MPam }^{1 / 2} \text { ) }\end{array}$ & $\begin{array}{c}\% \\
\text { Error }\end{array}$ \\
\hline $8.3 \times 10^{-3}$ & 24,1 & 991,59 & 963,47 & 2,8 & 25 & 1333,32 & 1351,7 & 1,4 \\
\hline $8.3 \times 10^{-4}$ & 45,1 & 959,36 & 958,79 & 0,1 & 22,2 & 1332,53 & 1344 & 0,9 \\
\hline $8.3 \times 10^{-5}$ & 117 & 956,63 & 957,63 & 0,1 & 54,7 & 1312,77 & 1320,9 & 0,6 \\
\hline
\end{tabular}

The maximum experimental fracture toughness in Mode I was found to be 1333.32 $\mathrm{MPam}^{1 / 2}$. This value was obtained from the parameters of $80^{\circ} \mathrm{C}, 15 \mathrm{~mm}$ crack length, and $8.3 \times 10^{-3} \mathrm{~s}^{-1}$ strain rate. The minimum experimental fracture toughness was found as 825.54 $\mathrm{MPam}^{1 / 2}$ as a result of experiments at $-20^{\circ} \mathrm{C}$ temperature, in $10 \mathrm{~mm}$ crack length, and $8.3 \times 10^{-5} \mathrm{~s}^{-1}$ strain rate. When crack length increased from $10 \mathrm{~mm}$ to $15 \mathrm{~mm}$ for the same strain rates a maximum increase of $14.1 \%$ was observed in Mod I fracture toughness at $20^{\circ} \mathrm{C}$. If the same compression was made for $80^{\circ} \mathrm{C}$ temperature it seen that the increased value was at $34.69 \%$. When the fracture toughness values were evaluated in terms of strain rate, there is a trend towards increasing the experimental fracture toughness value as the strain rate increases in both cold and hot temperatures. When the same temperature and the same crack lengths were evaluated, as a result of the experiments, while the strain rate increased from the lowest to the highest, the fracture toughness value increased by a maximum of $3.65 \%$. When experimental and numerical fracture toughness is compared, there is a maximum difference of around $3 \%$ between the results. 
Table 6. Experimental and FEM fracture toughness values in mixed mode (Mode I/II)

\begin{tabular}{|c|c|c|c|c|c|c|c|c|}
\hline \multirow{3}{*}{$\begin{array}{c}\text { Deformation } \\
\text { Rate }\left(\mathrm{s}^{-1}\right)\end{array}$} & \multicolumn{8}{|c|}{$\mathrm{a}=10 \mathrm{~mm}$} \\
\hline & \multirow{2}{*}{ 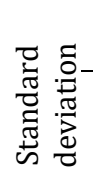 } & \multicolumn{3}{|c|}{$-20^{\circ} \mathrm{C}$} & \multirow{2}{*}{ 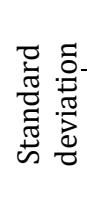 } & \multicolumn{3}{|c|}{$80^{\circ} \mathrm{C}$} \\
\hline & & $\begin{array}{c}\mathrm{K}_{\operatorname{mix}(\exp )} \\
\left(\mathrm{MPam}^{1 / 2}\right)\end{array}$ & $\begin{array}{c}\mathrm{K}_{\operatorname{mix}(\mathrm{num})} \\
\left(\mathrm{MPam}^{1 / 2}\right)\end{array}$ & $\begin{array}{l}\% \\
\text { Error }\end{array}$ & & $\begin{array}{c}\mathrm{K}_{\operatorname{mix}(\exp )} \\
\left(\mathrm{MPam}^{1 / 2}\right)\end{array}$ & $\begin{array}{c}\mathrm{K}_{\operatorname{mix}(\text { num })} \\
\left(\mathrm{MPam}^{1 / 2}\right)\end{array}$ & $\begin{array}{l}\% \\
\text { Error }\end{array}$ \\
\hline $8.3 \times 10^{-3}$ & 27.7 & 570.17 & 572.7 & 0.4 & 23.3 & 549.75 & 552 & 0.4 \\
\hline $8.3 \times 10^{-4}$ & 27.6 & 567.17 & 572.69 & 1 & 12.5 & 536.5 & 540.28 & 0.7 \\
\hline $8.3 \times 10^{-5}$ & 48.1 & 564.46 & 567.5 & 0.5 & 23.4 & 504.02 & 508.87 & 1 \\
\hline \multirow{3}{*}{$\begin{array}{c}\text { Deformation } \\
\text { Rate }\left(\mathrm{s}^{-1}\right)\end{array}$} & \multicolumn{8}{|c|}{$\mathrm{a}=15 \mathrm{~mm}$} \\
\hline & \multirow{2}{*}{ 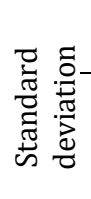 } & \multicolumn{3}{|c|}{$-20^{\circ} \mathrm{C}$} & \multirow{2}{*}{ 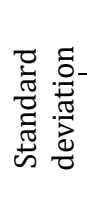 } & \multicolumn{3}{|c|}{$80^{\circ} \mathrm{C}$} \\
\hline & & $\begin{array}{c}\mathrm{K}_{\operatorname{mix}(\exp )} \\
\left(\mathrm{MPam}^{1 / 2}\right)\end{array}$ & $\begin{array}{c}\mathrm{K}_{\operatorname{mix}(\mathrm{num})} \\
\left(\mathrm{MPam}^{1 / 2}\right)\end{array}$ & $\begin{array}{l}\% \\
\text { Error }\end{array}$ & & $\begin{array}{c}\mathrm{K}_{\operatorname{mix}(\exp )} \\
\left(\mathrm{MPam}^{1 / 2}\right)\end{array}$ & $\begin{array}{c}\mathrm{K}_{\operatorname{mix}(\text { num })} \\
\left(\mathrm{MPam}^{1 / 2}\right)\end{array}$ & $\begin{array}{c}\% \\
\text { Error }\end{array}$ \\
\hline $8.3 \times 10^{-3}$ & 40.7 & 578.49 & 580.47 & 0.3 & 44.8 & 684.14 & 694.14 & 1.4 \\
\hline $8.3 \times 10^{-4}$ & 21.3 & 569.62 & 574.4 & 0.8 & 24 & 668.47 & 675.54 & 1 \\
\hline $8.3 \times 10^{-5}$ & 32.1 & 567.8 & 572.96 & 0.9 & 34.5 & 632.59 & 637.22 & 0.7 \\
\hline
\end{tabular}

In the Mode I/II crack tip opening status, the crack is exposed simultaneously to both the opening and shearing effect. Therefore, the fracture toughness values are smaller than the Mod I status. Thus, the maximum fracture toughness value $\left(684.14 \mathrm{MPam}^{1 / 2}\right)$ was found under $80^{\circ} \mathrm{C}$ temperature, $15 \mathrm{~mm}$ crack length, and $8.3 \times 10^{-3} \mathrm{~s}^{-1}$ deformation rate parameters. The Minimum fracture toughness $\left(504.02 \mathrm{MPam}^{1 / 2}\right)$ was found under $80^{\circ} \mathrm{C}$ temperature, $10 \mathrm{~mm}$ crack length, and at the $8.3 \times 10^{-5} \mathrm{~s}^{-1}$ deformation rate. For samples, which were tested at $-20^{\circ} \mathrm{C}$ and the same deformation rate, when the crack length increased from $10 \mathrm{~mm}$ to $15 \mathrm{~mm}$, a maximum $1.43 \%$ increase in mixed-mode fracture toughness was observed. When a similar comparison was made for $80^{\circ} \mathrm{C}$, this increase in fracture toughness was found to be $20.32 \%$. In the case of Mode I/II, when the fracture toughness values were evaluated in terms of deformation rate, the fracture toughness increased by a maximum of $9.07 \%$ as the deformation rate increased for the same temperature. For Mode I/II, when the toughness values obtained from the experimental and FEM analysis were compared, a maximum difference of $1.4 \%$ was observed between them.

\subsection{Fracture Energy Results}

In linear elastic fracture mechanics, another parameter that expresses fracture is energy. The J integral value is equal to the potential energy release rate for a virtual crack extension at any point along the crack front [51]. The equivalent of the experimentally calculated strain energy release rate $(G)$ value is the J integral value in the analysis of FEM [52]. The strain energy release rates and J integral values obtained by experimental and FEM method were given for Mode I in Table 7 and Mode I/II in Table 8.

The maximum strain energy release rate $\left(109 \mathrm{~mJ} / \mathrm{mm}^{2}\right)$ obtained experimentally in the case of Mod I was at $15 \mathrm{~mm}$ crack length, $80^{\circ} \mathrm{C}$, and $8.3 \times 10^{-4} \mathrm{~s}^{-1}$ deformation rate. The lowest strain energy release rate $\left(36.66 \mathrm{~mJ} / \mathrm{mm}^{2}\right)$ was found at $-20^{\circ} \mathrm{C}$ temperature, $10 \mathrm{~mm}$ crack length, and the lowest deformation rate under experimental conditions. Suitable with 
similar studies in the literature, the energy value is higher in the hot environment for the same deformation rate[23,53,54]. When the same deformation rate and temperatures are evaluated, the strain energy release rate depending on the two crack lengths varies by up to $26.22 \%$ at $-20^{\circ} \mathrm{C}$ temperature, while this change at $80^{\circ} \mathrm{C}$ temperature is $57.35 \%$. As the deformation rate increases in specimens tested under the same temperature and crack length, the energy value increased by a maximum of $7.27 \%$. When experimental and FEM energy values are compared, the highest error percentage is around $13 \%$.

Table 7. Comparison of strain energy release rate and J integral values for opening (Mode I) status.

\begin{tabular}{|c|c|c|c|c|c|c|}
\hline \multirow{3}{*}{$\begin{array}{c}\text { Deformation } \\
\text { Rate }\left(\mathrm{s}^{-1}\right)\end{array}$} & \multicolumn{6}{|c|}{$\mathrm{a}=10 \mathrm{~mm}$} \\
\hline & \multicolumn{3}{|c|}{$-20^{\circ} \mathrm{C}$} & \multicolumn{3}{|c|}{$80^{\circ} \mathrm{C}$} \\
\hline & $\begin{array}{c}\mathrm{G}_{\mathrm{IC}} \\
\left(\mathrm{mJ} / \mathrm{mm}^{2}\right)\end{array}$ & $\begin{array}{c}\text { Jint } \\
\left(\mathrm{mJ} / \mathrm{mm}^{2}\right)\end{array}$ & $\begin{array}{c}\% \\
\text { Error }\end{array}$ & $\begin{array}{c}\mathrm{G}_{\mathrm{IC}} \\
\left(\mathrm{mJ} / \mathrm{mm}^{2}\right)\end{array}$ & $\begin{array}{c}\text { Jint } \\
\left(\mathrm{mJ} / \mathrm{mm}^{2}\right)\end{array}$ & $\begin{array}{c}\% \\
\text { Error }\end{array}$ \\
\hline $8.3 \times 10^{-3}$ & 38.96 & 38.38 & 1.5 & 47.34 & 45.29 & 4.3 \\
\hline $8.3 \times 10^{-4}$ & 38.65 & 36.60 & 5.3 & 46.48 & 43.05 & 7.4 \\
\hline $8.3 \times 10^{-5}$ & 36.66 & 34.57 & 5.7 & 45.70 & 41.43 & 9.3 \\
\hline \multirow{3}{*}{$\begin{array}{c}\text { Deformation } \\
\text { Rate }\left(\mathrm{s}^{-1}\right)\end{array}$} & \multicolumn{6}{|c|}{$\mathrm{a}=15 \mathrm{~mm}$} \\
\hline & \multicolumn{3}{|c|}{$-20^{\circ} \mathrm{C}$} & \multicolumn{3}{|c|}{$80^{\circ} \mathrm{C}$} \\
\hline & $\begin{array}{c}\mathrm{G}_{\mathrm{IC}} \\
\left(\mathrm{mJ} / \mathrm{mm}^{2}\right)\end{array}$ & $\begin{array}{c}\text { Jint } \\
\left(\mathrm{mJ} / \mathrm{mm}^{2}\right)\end{array}$ & $\begin{array}{c}\% \\
\text { Error }\end{array}$ & $\begin{array}{c}\mathrm{G}_{\mathrm{IC}} \\
\left(\mathrm{mJ} / \mathrm{mm}^{2}\right)\end{array}$ & $\begin{array}{c}\text { Jint } \\
\left(\mathrm{mJ} / \mathrm{mm}^{2}\right)\end{array}$ & $\begin{array}{c}\% \\
\text { Error }\end{array}$ \\
\hline $8.3 \times 10^{-3}$ & 52.81 & 47.78 & 9.5 & 108.80 & 103.35 & 5.0 \\
\hline $8.3 \times 10^{-4}$ & 49.54 & 46.25 & 6.6 & 109.00 & 98.84 & 9.3 \\
\hline $8.3 \times 10^{-5}$ & 49.23 & 44.95 & 8.7 & 106.51 & 92.67 & 13.0 \\
\hline
\end{tabular}

Table 8. Comparison of strain energy release rate and J integral values for mixed-mode (Mode I/II) state

\begin{tabular}{|c|c|c|c|c|c|c|}
\hline \multirow{3}{*}{$\begin{array}{l}\text { Deformatio } \\
\text { n Rate }\left(\mathrm{s}^{-1}\right)\end{array}$} & \multicolumn{6}{|c|}{$\mathrm{a}=10 \mathrm{~mm}$} \\
\hline & \multicolumn{3}{|c|}{$-20^{\circ} \mathrm{C}$} & \multicolumn{3}{|c|}{$80^{\circ} \mathrm{C}$} \\
\hline & $\begin{array}{c}\text { GIC-mix } \\
\left(\mathrm{mJ} / \mathrm{mm}^{2}\right)\end{array}$ & $\begin{array}{c}\text { Jint } \\
\left(\mathrm{mJ} / \mathrm{mm}^{2}\right)\end{array}$ & $\begin{array}{c}\% \\
\text { Error }\end{array}$ & $\begin{array}{c}\text { GIC-mix } \\
\left(\mathrm{mJ} / \mathrm{mm}^{2}\right)\end{array}$ & $\begin{array}{c}J_{\text {int }} \\
\left(\mathrm{mJ} / \mathrm{mm}^{2}\right)\end{array}$ & $\begin{array}{c}\% \\
\text { Error }\end{array}$ \\
\hline $8.3 \times 10^{-3}$ & 16.94 & 17.13 & 1.1 & 18.25 & 17.71 & 3.0 \\
\hline $8.3 \times 10^{-4}$ & 17.07 & 16.91 & 0.9 & 17.85 & 16.59 & 7.1 \\
\hline $8.3 \times 10^{-5}$ & 16.93 & 16.27 & 3.9 & 15.91 & 14.36 & 9.7 \\
\hline \multirow{3}{*}{$\begin{array}{l}\text { Deformatio } \\
\text { n Rate }\left(\mathrm{s}^{-1}\right)\end{array}$} & \multicolumn{6}{|c|}{$\mathrm{a}=15 \mathrm{~mm}$} \\
\hline & \multicolumn{3}{|c|}{$-20^{\circ} \mathrm{C}$} & \multicolumn{3}{|c|}{$80^{\circ} \mathrm{C}$} \\
\hline & $\begin{array}{c}\text { GIC-mix } \\
\left(\mathrm{mJ} / \mathrm{mm}^{2}\right)\end{array}$ & $\begin{array}{c}\text { Jint } \\
\left(\mathrm{mJ} / \mathrm{mm}^{2}\right)\end{array}$ & $\begin{array}{c}\% \\
\text { Error }\end{array}$ & $\begin{array}{c}\text { GIC-mix } \\
\left(\mathrm{mJ} / \mathrm{mm}^{2}\right)\end{array}$ & $\begin{array}{c}\text { Jint } \\
\left(\mathrm{mJ} / \mathrm{mm}^{2}\right)\end{array}$ & $\begin{array}{c}\% \\
\text { Error }\end{array}$ \\
\hline $8.3 \times 10^{-3}$ & 17.47 & 17.25 & 1.3 & 28.28 & 26.90 & 4.9 \\
\hline $8.3 \times 10^{-4}$ & 17.23 & 16.42 & 4.7 & 27.71 & 24.50 & 11.6 \\
\hline $8.3 \times 10^{-5}$ & 17.13 & 15.83 & 7.6 & 25.06 & 21.01 & 16.2 \\
\hline
\end{tabular}

In the Mode I/II, the maximum strain energy release rate was observed as $28.28 \mathrm{~mJ} / \mathrm{mm}^{2}$. This value was obtained in a hot environment $\left(80^{\circ} \mathrm{C}\right)$, the highest deformation rate $\left(8.3 \times 10^{-}\right.$ ${ }^{3} \mathrm{~s}^{-1}$ ) and $15 \mathrm{~mm}$ crack length tests. The minimum strain energy release rate was found to be $15.91 \mathrm{~mJ} / \mathrm{mm}^{2}$ in experiments where the crack length was $10 \mathrm{~mm}$ under hot conditions and the lowest deformation rate. For tests performed at the same temperature and the same crack length, the energy value increased up to a maximum rate of $14.7 \%$ as the deformation rate increased. When the crack length increased from $10 \mathrm{~mm}$ to $15 \mathrm{~mm}$ at the 
same temperature and the same deformation rate, the strain energy release rate maximum increased up to $3.03 \%$ at $-20^{\circ} \mathrm{C}$ and $36.52 \%$ at $80^{\circ} \mathrm{C}$. In the case of Mode I/II, when comparing the energy values in experimental and FEM analyses, there is a maximum of $16.2 \%$ difference between them.

\section{Conclusions}

The effect of crack length, temperature and deformation rate on fracture behavior in S-2 glass/epoxy laminated composite plates have been investigated experimentally and numerically. The results of this study, which examined the changes in fracture toughness and fracture energy values to crack tip opening status of Mode I and Mode I/II, can be summarized as follows.

- Mode I is the most sensitive opening mode for two crack lengths with a $50 \%$ difference between them. The change in crack length, especially at $80^{\circ} \mathrm{C}$ temperature, is seriously felt in fracture toughness and energy values.

- For both Mode I and Mode I/II, fracture toughness is also seen to increase with the increase of deformation rate. Change in deformation rate at $80^{\circ} \mathrm{C}$ temperature in Mod I/II state is more effective than in Mod I state.

- S-2 glass/epoxy laminated composite structure is brittle in a cold environment and more ductile in a hot environment has a structure. It shows higher fracture toughness at $80^{\circ} \mathrm{C}$ due to its ductile structure. In Mod I there is a maximum 59\% fracture toughness difference between the two temperatures.

- In Mode I/II, the fracture toughness varied at most by $19.98 \%$ between the cold and hot temperature values. Indicates that a $45^{\circ}$ angle crack on S-2 glass/epoxy laminated composite to be used in cold and hot environments will be less affected by the change in temperature, crack length, and deformation rates.

- For the same temperature and crack length parameters, the strain energy release rate increases as the deformation rate increases. This trend applies to both Mod I and Mod I/II.

- As the temperature increases, the ductile material releases more energy. In Mode $\mathrm{I}$, when the ambient temperature reaches from $-20^{\circ} \mathrm{C}$ to $80^{\circ} \mathrm{C}$, the energy release rate value increases (maximum 190.53\%). This also applies to Mod I/II, although there is less variation (maximum 66.94\%).

- As a result of experiments, where crack length, temperature, and deformation rates are the same, the fracture toughness obtained of the Mode I is a maximum of $107.52 \%$ greater than the fracture toughness in the Mode I/II status. This ratio is $325.02 \%$ in terms of the strain energy release rate. These differences were found at $80^{\circ} \mathrm{C}$ experimental conditions. This result shows that the cracked S-2 glass/epoxy laminated composite structure is more sensitive to both Mode I opening mode and temperature.

- S-2 glass fiber reinforcement material is a type of material used especially in the aviation industry and also in outdoor environments. Experimentally and numerically, this study examined the S-2 glass/epoxy laminated composite structure at two different temperatures, such as $-20^{\circ} \mathrm{C}$ (for example, a cold climate zone winter temperature) and $80^{\circ} \mathrm{C}$ (for example, the conservation box of a heat source machine). If this material has different crack lengths and fracture modes, this study can be used as a reference source to predict fracture damage mechanisms by loaded with different deformation rates. 


\section{Acknowledgment}

This study was supported by Usak University Scientific Research Agency. Project Number: 2018/MF003 scientific research project.

\section{References}

[1] Yin S, Gong Y, Li W, Zhao L, Zhang J, Hu N. A novel four-linear cohesive law for the delamination simulation in composite DCB laminates. Compos Part B Eng 2020;180:107526. https://doi.org/10.1016/j.compositesb.2019.107526

[2] Healey R, Chowdhury NM, Chiu WK, Wang J. Experimental and numerical determination of mode II fracture toughness of woven composites verified through unidirectional composite test data. Polym Polym Compos 2019;27:557-66. https://doi.org/10.1177/0967391119853736

[3] Loutas T, Tsokanas P, Kostopoulos V, Nijhuis P, van den Brink WM. Mode I fracture toughness of asymmetric metal-composite adhesive joints. Mater Today Proc 2020. https://doi.org/10.1016/i.matpr.2020.03.075

[4] Andric P, Curtin WA. Atomistic modeling of fracture. Model Simul Mater Sci Eng 2019;27:013001. https://doi.org/10.1088/1361-651X/aae40c

[5] Bosbach B, Ohle C, Fiedler B. Structural health monitoring of fibre metal laminates under mode I and II loading. Compos Part A Appl Sci Manuf 2018;107:471-8. https://doi.org/10.1016/j.compositesa.2018.01.008

[6] Kaushik V, Ghosh A. Experimental and numerical characterization of Mode I fracture in unidirectional CFRP laminated composite using XIGA-CZM approach. Eng Fract Mech 2019;211:221-43. https://doi.org/10.1016/i.engfracmech.2019.01.038

[7] Insausti N, Adarraga I, De Gracia J, Arrese A, Mujika F. Numerical assessment of an experimental procedure applied to DCB tests. Polym Test 2020;82:106288. https://doi.org/10.1016/j.polymertesting.2019.106288

[8] Mousavi A, Aliha MRM, Imani DM. Effects of biocompatible Nanofillers on mixed-mode I and II fracture toughness of PMMA base dentures. J Mech Behav Biomed Mater 2020;103:103566. https://doi.org/10.1016/i.jmbbm.2019.103566

[9] Aliha MRM, Mousavi SS. Sub-sized short bend beam configuration for the study of mixed-mode fracture. Eng Fract Mech 2020;225:106830. https://doi.org/10.1016/j.engfracmech.2019.106830

[10] Kaynan O, Atescan Y, Ozden-Yenigun E, Cebeci H. Mixed Mode delamination in carbon nanotube/nanofiber interlayered composites. Compos Part B Eng 2018;154:186-94. https://doi.org/10.1016/i.compositesb.2018.07.032

[11] Li JG, Liu PF, Chu JK. Finite Element Analysis of Delamination Behaviors of Composite Laminates under Hygrothermal Environment Using Virtual Crack Closure Technique. J Fail Anal Prev 2019;19:147-53. https://doi.org/10.1007/s11668-019-00582-5

[12] Ravindran AR, Ladani RB, Wang CH, Mouritz AP. Synergistic mode II delamination toughening of composites using multi-scale carbon-based reinforcements. Compos Part A Appl Sci Manuf 2019;117:103-15. https://doi.org/10.1016/j.compositesa.2018.11.011

[13] Shahani AR, Abolfathitabar R, Shooshtar H. On the validity of LEFM methods to investigate the fracture behavior of angle-ply laminates. Compos Part B Eng 2019;160:249-53. https://doi.org/10.1016/i.compositesb.2018.10.013

[14] Torabi AR, Rahimi AS, Ayatollahi MR. Mixed mode I/II fracture prediction of blunt Vnotched nanocomposite specimens with nonlinear behavior by means of the Equivalent Material Concept. Compos Part B Eng 2018;154:363-73. https://doi.org/10.1016/j.compositesb.2018.09.025

[15] Torabi AR, Majidi HR, Cicero S, Ibáñez-Gutiérrez FT, Fuentes JD. Experimental verification of the Fictitious Material Concept for tensile fracture in short glass fibre 
reinforced polyamide 6 notched specimens with variable moisture. Eng Fract Mech 2019;212:95-105. https://doi.org/10.1016/j.engfracmech.2019.03.026

[16] Duin V, Pinheiro DC, Hyun M. Josefson, Lennart; van Duin, Stephen; de Carvalho Pinheiro, Bianca; Yang, Nana; Luo, Yu; Zamarin, Albert; Remes, Heikki; Roland, Frank; Gaiotti, Marco; Naoki, Osawa; Horn, Agnes M.; Kim, Myung Hyun; Mishra, Brajendra Committee V.3: Materials and fabricat. 2018. https://doi.org/10.3233/978-1-61499$\underline{\text { 864-8-143 }}$

[17] Brunner AJ. Fracture mechanics of polymer composites in aerospace applications. Elsevier Ltd; 2020. https://doi.org/10.1016/B978-0-08-102679-3.00008-3

[18] Foyouzat A, Bayesteh H, Mohammadi S. A brittle to ductile phase transition fracture analysis of shape memory polymers. Eng Fract Mech 2020;224:106751. https://doi.org/10.1016/i.engfracmech.2019.106751

[19] Farshidi A, Berggreen C, Carlsson LA. Low temperature mixed-mode debond fracture and fatigue characterisation of foam core sandwich. J Sandw Struct Mater 2018. https://doi.org/10.1177/1099636218779420

[20] Fakhri M, Haghighat Kharrazi E, Aliha MRM. Mixed mode tensile - In plane shear fracture energy determination for hot mix asphalt mixtures under intermediate temperature conditions. Eng Fract Mech 2018;192:98-113. https://doi.org/10.1016/i.engfracmech.2018.02.007

[21] Khashaba UA, Othman R, Najjar IMR. Development and characterization of structural adhesives for aerospace industry with alumina nanoparticles under shear and thermomechanical impact loads. Proc Inst Mech Eng Part G J Aerosp Eng 2020;234:490-507. https://doi.org/10.1177/0954410019875557

[22] Pan Z, Wu X, Wu L. Temperature rise caused by adiabatic shear failure in 3D braided composite tube subjected to axial impact compression. J Compos Mater 2019. https://doi.org/10.1177/0021998319877558

[23] Pini T, Briatico-Vangosa F, Frassine R, Rink M. Matrix toughness transfer and fibre bridging laws in acrylic resin based CF composites. Eng Fract Mech 2018;203:115-25. https://doi.org/10.1016/j.engfracmech.2018.03.026

[24] Rahmani A, Choupani N, Kurtaran H. Thermo-fracture analysis of compositealuminum bonded joints at low temperatures: Experimental and numerical analyses. Int J Adhes Adhes 2019;95:102422. https://doi.org/10.1016/i.ijadhadh.2019.102422

[25] Aktas M, Balcioglu HE, Külahli G. Strain rate effects on tensile and compressive behaviour of woven-knitting glass/epoxy composites. Adv Compos Lett 2013;22:13-9. https://doi.org/10.1177/096369351302200103

[26] Jia Z, Yuan G, Hui D, Feng X, Zou Y. Effect of high loading rate and low temperature on mode I fracture toughness of ductile polyurethane adhesive. J Adhes Sci Technol 2019;33:79-92. https://doi.org/10.1080/01694243.2018.1546364

[27] AZO Materials. S-Glass 2001:1-3. https://www.azom.com/properties.aspx?ArticleID=769 (accessed July 23, 2019).

[28] HEXION® Specialty Chemicals. Laminating Resin MGS® L 285 Hardeners MGS® 285 287 Technical Data Sheet n.d. https://www.hexion.com/en-US/search?id=30303 (accessed July 23, 2019).

[29] Chabchoub M, Vieille B, Moutou Pitti R. Numerical estimation of the mode I strain energy release rate in woven-ply thermoplastic-based composites at high temperature based on G $\theta$ method. Theor Appl Fract Mech 2019;101:169-77. https://doi.org/10.1016/j.tafmec.2019.02.018

[30] Satyanarayana A, Gattu M. Effect of displacement loading rates on mode-I fracture toughness of fiber glass-epoxy composite laminates. Eng Fract Mech 2019;218:106535. https://doi.org/10.1016/j.engfracmech.2019.106535

[31] Siddique A, Abid S, Shafiq F, Nawab Y, Wang H, Shi B, et al. Mode I fracture toughness of fiber-reinforced polymer composites: A review. J Ind Text 2019. https://doi.org/10.1177/1528083719858767 
[32] Torabi AR, Pirhadi E. Failure analysis of round-tip V-notched laminated composite plates under mixed mode I/II loading. Theor Appl Fract Mech 2019;104:102342. https://doi.org/10.1016/j.tafmec.2019.102342

[33] Vieille B, Gonzalez JD, Bouvet C. Fracture mechan ics of hybrid composites with ductile matrix and brittle fibers: Influence of temperature and constraint effect. J Compos Mater 2019;53:1361-76. https://doi.org/10.1177/0021998318802613

[34] Jamali J, Fan Y, Wood JT. The mixed-mode fracture behavior of epoxy by the compact tension shear test. Int J Adhes Adhes 2015;63:79-86. https://doi.org/10.1016/j.ijadhadh.2015.08.006

[35] Choupani N. Experimental and numerical investigation of the mixed-mode delamination in Arcan laminated specimens. Mater Sci Eng A 2008;478:229-42. https://doi.org/10.1016/j.msea.2007.05.103

[36] Aliha MRM, Shaker S, Keymanesh MR. Low temperature fracture toughness study for bitumen under mixed mode I + II loading condition. Eng Fract Mech 2019;206:297-309. https://doi.org/10.1016/j.engfracmech.2018.11.037

[37] Kaman MO. Stress Intensity Factor Analysis of Antisymmetrically Carbon / Epoxy Laminated Composite Plates with Different. Turkish J Sci Technol 2011;6:61-74.

[38] Kaman MO. Effect of fiber orientation on fracture toughness of laminated composite plates $\quad\left[0^{\circ} / \theta^{\circ}\right] \mathrm{s}$. Eng Fract $\quad$ Mech 2011;78:2521-34 https://doi.org/10.1016/i.engfracmech.2011.06.005

[39] Arasan Ş, Aktaş M, Balcıoğlu HE. Fracture toughness of woven glass and carbon reinforced hybrid and non-hybrid composite plates. Polym Compos 2018;39:783-93. https://doi.org/10.1002/pc.23999

[40] Fu, Shao-Yun_ Lauke, Bernd_ Mai Y-W. Science and engineering of short fibrereinforced polymer composites (2019, WP). Matthew Deans; 2019. https://doi.org/10.1016/B978-0-08-102623-6.00005-6

[41] Hossein Abadi R, Refah Torun A, Mohammadali Zadeh Fard A, Choupani N. Fracture characteristics of mixed-mode toughness of dissimilar adherends (cohesive and interfacial fracture). J Adhes Sci Technol 2020;34:599-615. https://doi.org/10.1080/01694243.2019.1674102

[42] Balcioglu HE, Yalcin D. The Determination of Fracture Characterization of Knitted Fabric Reinforced Composites Using Arcan Test. Fibers Polym 2020;21:849-63. https://doi.org/10.1007/s12221-020-9619-z

[43] Manzella AF, Gama BA, Gillespie JW. Effect of punch and specimen dimensions on the confined compression behavior of S-2 glass/epoxy composites. Compos Struct 2011;93:1726-37. https://doi.org/10.1016/j.compstruct.2010.11.006

[44] Kaya Z, Ersen H, Halit B. The strain rate and temperature effects on the static and dynamic properties of S2 glass / epoxy composites. Appl Phys A 2020;126:1-15. https://doi.org/10.1007/s00339-020-03855-1

[45] Albiter NL. On the fracture behavior of ductile polymer films : notch quality, essential work of fracture, J-integral, and crack tip opening displacement. Universitat Politècnica de Catalunya-BarcelonaTech,

2018. https://doi.org/10.1016/j.engfracmech.2017.01.019

[46] Kim JH, Paulino GH. Mixed-mode J-integral formulation and implementation using graded elements for fracture analysis of nonhomogeneous orthotropic materials. Mech Mater 2003;35:107-28. https://doi.org/10.1016/S0167-6636(02)00159-X

[47] Zou G, Chen H. Path-dependent J-integrals under mixed-mode loads of mode I and mode II. Theor Appl Fract Mech 2018;96:380-6. https://doi.org/10.1016/i.tafmec.2018.05.014

[48] Balcıoğlu HE. Fracture Behaviors of SiC Particle Filled and Jute Fiber Reinforced Natural Composites. J Nat Fibers 2020;00:1-18. https://doi.org/10.1080/15440478.2020.1811186 
[49] Rocha AVM, Akhavan-Safar A, Carbas R, Marques EAS, Goyal R, El-zein M, et al. Fatigue crack growth analysis of different adhesive systems: Effects of mode mixity and load level. Fatigue Fract Eng Mater Struct 2020;43:330-41. https://doi.org/10.1111/ffe.13145

[50] Zeinedini A. A novel fixture for mixed mode I/II/III fracture testing of brittle materials. Fatigue Fract Eng Mater Struct 2019;42:838-53. https://doi.org/10.1111/ffe.12955

[51] Hein J, Kuna M. A generalized J-integral for thermal shock analyses of 3D surface cracks in spatially and temperature dependent materials. Theor Appl Fract Mech 2017;92:318-30. https://doi.org/10.1016/i.tafmec.2017.04.013

[52] Vieille B, Chabchoub M, Gautrelet C. Influence of matrix ductility and toughness on strain energy release rate and failure behavior of woven-ply reinforced thermoplastic structures at high temperature. Compos Part B Eng 2018;132:125-40. https://doi.org/10.1016/i.compositesb.2017.08.011

[53] Coronado P, Viña JA, Argüelles A, Sánchez S. Fractographic Analysis of the Temperature Influence in the Mode I Fatigue Delamination of Carbon/Epoxy Composites. Proceedings 2018;2:1477. https://doi.org/10.3390/proceedings2231477

[54] Sales R de CM, Gusmão SR, Gouvêa RF, Chu T, Marlet JMF, Cândido GM, et al. The temperature effects on the fracture toughness of carbon fiber/RTM-6 laminates processed by VARTM. J Compos Mater 2017;51:1729-41. https://doi.org/10.1177/0021998316679499 